\title{
ASO Author Reflections: Chyle Leak: No Long-Term Impact on Survival
}

\author{
Pamela Milito, MD, and Alexander W. Phillips, MD \\ Northern Oesophago-Gastric Cancer Unit, Royal Victoria Infirmary, Newcastle-upon-Tyne, UK
}

\section{PAST}

Chyle leak is a well-recognised complication of transthoracic esophagectomy with a reported incidence of 1 to $9 \% .^{1}$ This complication has been associated with a higher rate of morbidity and mortality. ${ }^{2}$ A variety of strategies have been postulated in the past, which have included reoperation, embolization, and dietary modulation with use of total parenteral nutrition or enteral feeding using medium-chain triglyceride (MCT) diets. ${ }^{3,4}$ However, treatment of this complication needs to be tailored to the individual clinical scenario to determine which strategy may be most appropriate.

\section{PRESENT}

The present study indicates that surgical outcomes of patients developing chyle leak were similar to those who had an uneventful surgery, except for the length of critical care stay which was longer for those developing a chyle leak. ${ }^{5}$ More importantly, a chyle leak was not associated with any detrimental long-term effect. In particular, there was no significant difference in overall survival regardless of tumour histology between patients who developed a leak and those who did not. Conservative treatment, with the implementation of MCT feed, may address many leaks that are encountered. However, high-volume leaks are likely to require surgical intervention, which should not be feared, because it is safe and effective.

(C) The Author(s) 2020

First Received: 9 November 2020

Accepted: 10 November 2020;

Published Online: 21 November 2020

A. W. Phillips, MD

e-mail: awphillips@doctors.net.uk

\section{FUTURE}

An early detection and standardized treatments for chyle leakage after transthoracic esophagectomy may help to improve the morbidity and mortality of this complication. The range of available approaches vary. However, minimally invasive treatment, such as embolization of the thoracic duct, is not widely available. In the future, newer surgical techniques, such as robotic surgery or the use of augmented reality, may help to provide a better intraoperative identification of problems that will reduce the incidence.

OPEN ACCESS This article is licensed under a Creative Commons Attribution 4.0 International License, which permits use, sharing, adaptation, distribution and reproduction in any medium or format, as long as you give appropriate credit to the original author(s) and the source, provide a link to the Creative Commons licence, and indicate if changes were made. The images or other third party material in this article are included in the article's Creative Commons licence, unless indicated otherwise in a credit line to the material. If material is not included in the article's Creative Commons licence and your intended use is not permitted by statutory regulation or exceeds the permitted use, you will need to obtain permission directly from the copyright holder. To view a copy of this licence, visit http://creativecommons. org/licenses/by/4.0/.

FUNDING None declared.

\section{REFERENCES}

1. Lagarde SM, Omloo JMT, de Jong $\mathrm{K}$, et al. Incidence and management of chyle leakage after esophagectomy. Ann Thorac Surg. 2005;80:449-54.

2. Bolger C, Walsh TN, Tanner WA, et al. Chylothorax after oesophagectomy. Br J Surg. 1991;78(5):587-8.

3. Shackcloth M, McCarron E, Poullis M, et al. Management of thoracic duct injuries after oesophagectomy (Br J Surg 2001;88:1442-8). Letter 2. Br J Surg. 2002;89(6):809.

4. Cope C, Kaiser LR. Management of unremitting chylothorax by percutaneous embolization and blockage of retroperitoneal 
lymphatic vessels in 42 patients. $J$ Vasc Interv Radiol. 2002;13:1139-48.

5. Milito P, Chmelo J, Dunn L, et al. Chyle leak following radical enbloc esophagectomy with 2 field nodal dissection: predisposing factors: management and outcomes. Ann Surg Oncol. https://doi. org/10.1245/s10434-020-09399-1. (in press).
Publisher's Note Springer Nature remains neutral with regard to jurisdictional claims in published maps and institutional affiliations. 